\title{
Replacement of soybean meal by treated castor meal in supplements for grazing heifer during the dry-rainy season period
}

\author{
Lívia Vieira de Barros ${ }^{1}$, Mário Fonseca Paulino ${ }^{2}$, Edenio Detmann ${ }^{2}$, Sebastião de Campos \\ Valadares Filho ${ }^{2}$, Sidnei Antonio Lopes ${ }^{1}$, Anilza Andréia da Rocha ${ }^{1}$, Ériton Egidio Lisboa \\ Valente $^{1}$, Daniel Mageste de Almeida ${ }^{1}$
}

${ }^{1}$ DZO/UFV - Viçosa, MG.

2 DZO/UFV - Viçosa, MG. Pesquisador INCT-CA.

ABSTRACT - The objective of this work was to evaluate the effect of multiple supplement with different levels of castor meal (Ricinus communis L.) treated with calcium oxide on intake, on the total apparent digestibility of dietary components, on the efficiency of microbial synthesis and on the performance of beef heifers grazing Brachiaria decumbens during the dryrainy transition period. The experimental area was composed of five 2.5-ha paddocks with availability of potentially digestible dry matter of 2,858.4 kg/ha. It was used 25 Nellore heifers and 10 crossbred with predominance of Zebu breed heifers at 13 months of age and body weight of $210 \pm 0.8 \mathrm{~kg}$ in a completely randomized experimental design. Supplements contained approximately $25 \%$ of crude protein (CP) and they were formulated with $0 ; 33 ; 67$ and $100 \%$ of castor meal replacing soybean meal. Daily weight gain was $366.1 \mathrm{~g}$ for animals in the control group and 439.7; 478.9; 556.3; and 493.9, respectively for those fed supplements with $100 \%$ of soybean meal and 33, 67 and $100 \%$ castor meal. There was no effect of treated castor meal levels on daily weight gain of the animals, which was higher in those animals fed supplements. Levels of castor meal had decreasing linear effect on intakes of dry matter (DM), organic matter (OM), ether extract (EE), digested dry matter and digestible neutral detergent fiver and on the intake of total digestible nutrients. Coefficients of apparent digestibility of DM, $\mathrm{OM}, \mathrm{CP}, \mathrm{EE}$ and non-fibrous carbohydrates were greater for animals under supplementation. Microbial efficiency, expressed in g of crude protein per kg of consumed TDN, did not differ among groups. Replacement of soybean meal by castor meal treated with calcium oxide does not harm animal performance.

Key Words: biodisel, Brachiaria decumbens, nutritional parameters, supplementation

\section{Substituição do farelo de soja por farelo de mamona tratado em suplementos para novilhas em pastejo no período de transição seca-águas}

RESUMO - Objetivou-se avaliar o efeito de suplementos múltiplos com diferentes níveis de farelo de mamona (Ricinus communis L.) tratado com óxido de cálcio sobre o consumo, a digestibilidade aparente total de componentes da dieta, a eficiência de síntese microbiana e o desempenho produtivo de novilhas de corte em pastagem de Brachiaria decumbens durante o período de transição seca-águas. A área experimental foi composta de cinco piquetes de 2,5 hectares, com disponibilidade de matéria seca potencialmente digestível de 2.858,4 kg/ha. Utilizaram-se 25 novilhas da raça Nelore e 10 mestiças com predominância de sangue zebu com idade e peso médio iniciais, respectivamente, de 13 meses e $210 \pm 0.8 \mathrm{~kg}$ de peso corporal em um delineamento experimental inteiramente casualizado. Os suplementos continham aproximadamente 25\% de proteína bruta (PB) e foram formulados com 0; 33; 67 e 100\% de farelo de mamona em substituição ao farelo de soja. O ganho médio diário foi de 366,1 g para os animais do grupo controle e 439,7; 478,9; 556,3; e 493,9, respectivamente, para aqueles alimentados com os suplementos com 100\% de farelo de soja e com 33, 67 e 100\% de farelo de mamona. Não houve efeito dos níveis de farelo de mamona tratado sobre o ganho médio diário dos animais, que foi maior naqueles que receberam suplemento. Os níveis de farelo de mamona tiveram efeito linear decrescente sobre os consumos de matéria seca (MS), matéria orgânica (MO), extrato etéreo (EE), matéria seca digerida e fibra em detergente neutro digestível e o consumo de nutrientes digestíveis totais. Os coeficientes de digestibilidade aparente da MS, MO, PB, EE e carboidratos não-fibrosos foram maiores para os animais sob suplementação. A eficiência microbiana, expressa em g de proteína bruta por kg de NDT consumido, não diferiu entre os grupos. A substituição do farelo de soja por farelo de mamona tratado com óxido de cálcio não prejudica o desempenho dos animais.

Palavras-chave: biodiesel, Brachiaria decumbens, parâmetros nutricionais, suplementação 


\section{Introduction}

Nowadays, supplementation of bovines in pasture is the alternative that most increases as a strategy for increase in productivity (more than 2000\% from 1991 to 2006) (ANUALPEC, 2007). The use of alternative protein sources that do not implicate on the animal performance is a feasible option to reduce costs with supplementation, making it possible the optimization of animal production.

The expectation of gradual increase of biodiesel participation in the world energetic matrix created opportunities for ruminants production through the potential offer of meals or cakes obtained after extraction of seed oil, which are the main co-products of the biodiesel productive chain.

Among many options of available oilseeds, castor culture (Ricinnus communis L.) stands out because of its high exploration potential in marginalized regions of the development process and by the high potential productivity of the oil. The presence of toxic compounds (ricine and ricinina) as well as the technological shortage that provides obtainment of a safe food with competitive prices were commonly pointed as the main factors that restrain its adoption in animal feeding (Severino, 2005). In recent studies, Oliveira et al. (2010) showed that it is possible to make efficient deintoxication of castor seed meal by calcium oxide, obtaining a safe product for animal feeding.

Therefore, the objective of this work was to evaluate the need of supplementation and the nutritional parameters, the efficiency of microbial synthesis and productive performance of Nellore heifers and crossbreed heifers with predominance of Zebu breed under pasture in the dry/rainy transitional season by receiving multiple supplements with partial or total replacing of soybean meal by castor seed meal treated with calcium oxide.

\section{Material and Methods}

The experiment was carried out the Setor de Bovinocultura de Corte in Departamento de Zootecnia at Universidade Federal de Viçosa, during the dry/rainy transition season from October 2008 to January 2009, lasting for 84 days.

During the experimental period, the observed average for maximum temperature was $26.6^{\circ} \mathrm{C}, 18.3^{\circ} \mathrm{C}$ for minimum temperature and $285.4 \mathrm{~mm}$ for rainfall precipitation.

It was used 35 heifers in which 25 were Nellore breed and 10 crossbreed with predominance of Zebu breed at 13 months of age and initial average weight of $210.5 \pm 0.8 \mathrm{~kg}$, divided in five treatments.
The experimental design was a complete random design with five treatments and seven replicates for each treatment. The experimental area assigned for the animals were composed by five 2.5 ha paddocks with decumbens grass provided with covered drinkers and feeders.

It was evaluated four supplements (Table 1) with approximately 25\% (\%MS) of crude protein. Soybean meal (SM) was progressively substituted by castor seed meal treated with calcium oxide (CM) at the levels of $0,33,67$, and $100 \%$ for the treatments $\mathrm{CM}_{0}, \mathrm{CM}_{33}, \mathrm{CM}_{67}$ e $\mathrm{CM}_{100}$, respectively, plus a control group in which animals received only mineral mixture (MM) ad libitum. The urea:ammonium sulphate mixture (9:1) was used to adjust crude protein level of the supplements because of the differences of crude protein among protein feed used, but the variation in urea level among supplement was $2 \%$ at most based on the natural matter of the supplement, aiming that urea level in the supplement did not affect the performance of the animals. The supplements were supplied at the quantity of $1.0 \mathrm{~kg} / \mathrm{animal} /$ day.

The treatment of castor seed meal was performed by using lime solution $(\mathrm{CaO})$ diluting each $\mathrm{kg}$ in 10 liters of water and applied at $60 \mathrm{~g}$ of lime/meal $\mathrm{kg}$ based on the natural matter according to Oliveira et al. (2007).

At the beginning of the experiment, all the animals were submitted to ecto and endoparasites control and during the experimental period, when it was needed, actions against ticks and horn-flies were taken.

Animals were weighed after a 14 -hour water and food fast at the beginning and at the end of the experiment. Animals were rotated among paddocks every 14 days aiming at minimizing possible interferences on the results due to differences among paddocks (pasture availability, localization of drinkers and troughs, relief, shading, etc.). The total weight gain (TWG) was quantified by the difference between the final and initial weight, after fast,

Table1 - Percentage composition of the supplement based on the natural matter

\begin{tabular}{|c|c|c|c|c|c|}
\hline \multirow[t]{2}{*}{ Item } & \multirow{2}{*}{$\begin{array}{l}\text { Mineral } \\
\text { mixture }\end{array}$} & \multicolumn{4}{|c|}{ Level of castor seed meal (\%) } \\
\hline & & 0 & 33 & 67 & 100 \\
\hline \multicolumn{6}{|l|}{ Ingredient (\%) } \\
\hline Mineral mixture $(\mathrm{MM})^{1}$ & 100.0 & 6.0 & 6.0 & 6.0 & 6.0 \\
\hline Ground sorghum grain & 一 & 20.5 & 20.5 & 20.5 & 20.5 \\
\hline Ground corn grain & - & 20.5 & 20.5 & 20.5 & 20.5 \\
\hline Soybean meal & - & 50.0 & 33.5 & 16.5 & - \\
\hline Castor seed meal & - & - & 16.5 & 33.5 & 50.0 \\
\hline Urea/AS (9:1) & - & 1.0 & 1.5 & 2.5 & 3.0 \\
\hline Wheat meal & - & 2.0 & 1.5 & 0.5 & - \\
\hline
\end{tabular}

${ }^{1}$ Percentage composition: dicalcium phosphate - 50,00; sodium chloride - 47,775, zinc sulphate -1.40 ; copper sulphate -0.70 ; cobalt sulphate -0.05 ; potassium iodate -0.05 and sodium selenit 0.025 . 
and daily average weight gain (DAG) was the ratio among total weight gain and the number of experimental days (84).

Every 14 days of each 28-day period, forage samples were collected in the different paddocks by cutting at $5 \mathrm{~cm}$ above ground in four areas delimitated by a $0.5 \times 0.5$ m metal square, random chosen in each experimental paddock. The samples were oven-dried $\left(55^{\circ} \mathrm{C}, 72\right.$ hours $)$, to remove part of the water present in the sample, allowing the milling and storage of the sample.

The DMpd (\% DM) was estimated accordingly to the following equation (Paulino et al., 2008):

$\mathrm{DMpd}=0.98 \times(100-\mathrm{NDF})+(\mathrm{NDF}-\mathrm{iNDF})$ where: $\mathrm{NDF}=$ neutral detergent fiber and $\mathrm{iNDF}=$ indigestible neutral detergent fiber, as \% of DM.

The samples for qualitative evaluation of the pasture consumed by animals were obtained through hand simulation of the pasture every 14 days, in which along with samples of concentrates, they were evaluated for levels of dry matter, crude protein, ether extract (EE), lignin (through permanganate). Those analyses were performed by methods described in Silva \& Queiroz (2002).

For analyses of concentration of neutral detergent fiber (NDF), the samples were treated with alpha amylase thermostable without using sodium sulfite, corrected for nitrogen residuals (Licitra et al., 1996) and ash (Mertens, 2002).

Analyses of NDF and ADF were carried out in Ankon system. The quantification of non protein nitrogen (NPN) of the feeds was carried out according to Licitra et al. (1996).

The non-fibrous carbohydrates corrected for protein and ash (NFC) were estimated according to recommendations by Hall (2000) using the following equation:

$$
\begin{gathered}
\text { NFC }=100-[(\% \mathrm{CP}-\% \mathrm{UCP}+\% \text { de urea })+\% \text { NDFom(n) } \\
+\% \mathrm{EE}+\% \text { ash })]
\end{gathered}
$$

where: $\mathrm{UCP}=\mathrm{CP}$ in the supplement from urea; $\mathrm{NDFom}(\mathrm{n})=$ NDF correct for ash and protein.

To evaluate intake and digestibility of the consumed diet, starting on the $48^{\text {th }}$ of the experimental period, it was carried out a trial with nine days of duration in which 6 were for adaptation of the animals to the markers. Titanium dioxide was mixed to the supplement at the quantity of $10 \mathrm{~g} /$ animal (1\% of the supplement) so the measure of the supplement individual intake (Titgemeyer et al., 2001) could be done. In addition to $\mathrm{TiO}_{2}$, animals received $10 \mathrm{~g}$ of chromic oxide $\left(\mathrm{Cr}_{2} \mathrm{O}_{3}\right)$ which was used to estimate fecal excretion, applied through oral via with the aid of an applicator introduced directly in the esophagus always around 9 a.m. On the seventh, eighth and ninth days, fecal collection sampling were realized at 3 p.m., 11 a.m. and 7 a.m., respectively, aiming at obtaining representative fecal samples during the experimental period. Excretion of fecal dry matter was estimated by considering the ratio among quantity of the supplied indicator and its concentration in the feces.

The estimate of individual intake of the supplement was obtained through the following equation:

$$
\text { IISup }=\mathrm{FE} \times \mathrm{iF} / \mathrm{iSup}
$$

where: IISup = individual intake of the supplement (kg/day); $\mathrm{FE}=$ fecal excretion (kg/day); iF = concentration of the indicator in the feces $(\mathrm{g} / \mathrm{kg})$; iSup = concentration of the indicator in the supplement $(\mathrm{g} / \mathrm{kg})$.

Estimation of voluntary intake of bulk dry matter (VIDM) was performed by using as internal indicator the indigestible NDF (iNDF), adapting the equation proposed by Detmann et al. (2001):

$\operatorname{VIDM}(\mathrm{kg} /$ day $)=\{[(\mathrm{FE} \times \mathrm{CIF})-$ IS $] /$ CIFO $\}$ in which: $\mathrm{FE}=$ fecal excretion (kg/day); $\mathrm{CIF}=$ concentration of the indicator in the feces $(\mathrm{kg} / \mathrm{kg})$; IS = intake of the internal indicator from the supplement $(\mathrm{kg} / \mathrm{day})$ and $\mathrm{CIFO}=$ concentration of the indicator in the forage $(\mathrm{kg} / \mathrm{kg})$.

The total dry matter intake was the sum of the bulk and concentrate intake. The intakes of digested dry matter (DDM) and of digested neutral detergent fiber (DNDF) were calculated by multiplying the dry matter and NDF intake by coefficients of total apparent digestibility of dry matter and NDF, respectively.

Estimation of iNDF in the feces, in the pasture samples obtained by grazing manual simulation and in the supplements was obtained after in situ incubation for 240 hours as suggested by Casali et al. (2008). The ether extract digestibility was estimated according to Detmann et al. (2006).

On the last day of the digestibility trial, it was done a spot sample collection of blood and urine $(10 \mathrm{~mL})$ through spontaneous urination of the animals approximately four hours after the supply of the supplement. After the collection, urine samples were diluted in $40 \mathrm{~mL}$ of $\mathrm{H}_{2} \mathrm{SO}_{4}$ $0.036 \mathrm{~N}$ (Valadares et al., 1999) and then frozen $\left(-20^{\circ} \mathrm{C}\right)$ for further quantification of contents of total nitrogen, creatinine, urea and purine derivatives. Blood samples were collected at the end of urine collection period, using vacuum collection tubes, with coagulation accelerator gel. The samples were immediately centrifuged and the serum was frozen $\left(20^{\circ} \mathrm{C}\right)$ for further analyses of $\mathrm{N}$-urea content. Analyses for allantoin content in the urine were carried out by the colorimetric method, accordingly to Fujihara et al. (1987). The calculation of daily urinary volume was performed by using the relation creatinine daily excretion - 
adopting as reference the equation proposed by Chizzotti et al. (2006) and its concentration in the spot samples:

$$
\mathrm{EC}_{(\mathrm{mg} / \mathrm{kgPC})}=32.27-0.01093 \times \mathrm{PC}
$$

Therefore, the daily urinary excretion of nitrogen compounds was the product of its concentration in the spot samples and the estimated value of urinary volume.

Total excretion of purine derivatives was calculated by the sum of quantities of allantoin and uric acid excreted in the urine. The absorbed purine ( $\mathrm{Y}, \mathrm{mmol} / \mathrm{day}$ ) was calculated from the exception of purine derivatives ( $\mathrm{X}, \mathrm{mmol} /$ day), through the equations:

$$
\mathrm{Y}=\left(\mathrm{X}-0.385 \mathrm{PC}^{0.75}\right) / 0.85
$$

in which: 0.85 = the recovery of purine absorbed as purine derivatives and $0.385 \mathrm{PC}^{0.75}=$ the endogenous contribution for excretion of purines (Verbic et al., 1990).

The ruminal synthesis of nitrogen compounds ( $\mathrm{Y}, \mathrm{g}$ Nmic/day), was calculated in function of the absorbed purine (X, mmol/day), by using the equation described by Chen \& Gomes (1992), except for the relation N purine:N total bacteria of 0.134 accordingly to Valadares et al. (1999):

$$
\mathrm{Y}=70 \mathrm{X} /(0.83 \times 0.134 \times 1000)
$$

in which: $70=$ the content of $\mathrm{N}$ purine $(\mathrm{mgN} / \mathrm{mol}) ; 0.134$, the relation of $\mathrm{N}$ purines: $\mathrm{N}$ total in the bacteria; and $0.83=$ the digestibility of bacterial purines.

The statistical procedures were performed by the computer program SAS, adopting 0.10 as critical level of probability for the Type I standard error. Comparisons among observed means were carried out through decomposition of the square sum for treatments in orthogonal contrasts related to comparison among supplementation and no supplementation and in relation to the level of castor seed meal treated in the supplements.

\section{Results and Discussion}

The animal performance on pasture is directly related to the quantity and quality of the available forage. Accordingly to Paulino et al. (2008), the potentially digestible dry matter is an integrating measure of quantitative and qualitative aspects of the pasture, which allows greater preciseness in the real evaluation of capacity of support and performance of animal in the used area. The average availabilities of the dry matter and potentially digestible dry matter during all the experimental period were 4,328.3 and 2,858.4 kg/ha, respectively (Table 2).

Brachiaria decumbens obtained by manual grazing simulation presented average level of crude protein of $8.74 \%$ (Table 3), higher than the minimal value of $7-8 \%$ of the crude protein in the basal diet reported by Lazzarini et al. (2009) as needed to achieve suitable use of the neutral detergent fiber of the low quality basal forage which is the main energy source for animals raised in pasture. However, below the $10 \%$ cited by Sampaio et al. (2009) as the level that optimizes the use of energetic substrate of the forage, which justifies the supplementation

Table 2 - Total dry matter (DM) and potentially digestible dry matter (DMpd) availabitlity during the experimental periods

\begin{tabular}{|c|c|c|c|c|c|c|}
\hline \multirow[t]{2}{*}{ Item } & \multicolumn{4}{|c|}{ Castor seed meal level (\%) } & \multirow[b]{2}{*}{ B. decumbens ${ }^{1}$} & \multirow[b]{2}{*}{ B. decumbens ${ }^{2}$} \\
\hline & 0 & 33 & 67 & 100 & & \\
\hline Dry matter, DM (\%) & 87.11 & 88.04 & 89.05 & 89.98 & $34.72 \pm 0.59^{*}$ & $41.96 \pm 0.14^{*}$ \\
\hline Organic matter (\% DM) & 96.93 & 96.11 & 95.26 & 94.43 & $90.65 \pm 0.33$ & $91.68 \pm 0.33$ \\
\hline Crude protein (\% DM) & 25.4 & 24.5 & 24.3 & 23.28 & $8.74 \pm 0.12$ & $7.51 \pm 0.43$ \\
\hline NDICP (\% total nitrogen) & 10.92 & 12.11 & 13.28 & 14.47 & $42.77 \pm 2.66$ & $40.84 \pm 2.01$ \\
\hline Ether extract (\% DM) & 1.41 & 1.39 & 1.36 & 1.34 & $1.74 \pm 0.29$ & $1.22 \pm 0.30$ \\
\hline Neutral detergen fiber (\% DM) & 12.16 & 16.21 & 20.2 & 24.23 & $68.03 \pm 0.32$ & $67.46 \pm 0.45$ \\
\hline NDFom(n) (\% DM) & 10.43 & 13.19 & 15.9 & 18.65 & $64.47 \pm 0.38$ & $62.55 \pm 2.01$ \\
\hline Non fiber carbohydrates $(\% \mathrm{DM})^{3}$ & 61.31 & 59.46 & 57.75 & 56.02 & $15.71 \pm 0.60$ & $19.82 \pm 0.30$ \\
\hline Acid detergent fiber (\% DM) & 3.91 & 7.8 & 11.75 & 15.64 & $42.73 \pm 0.53$ & $41.42 \pm 0.63$ \\
\hline Non protein nitrogen (\% total nitrogen) & 7.87 & 9.37 & 10.93 & 12.44 & $26.84 \pm 1.29$ & $24.6 \pm 0.97$ \\
\hline Indigestible neutral detergent fiber (\% DM) & 1.72 & 5.79 & 9.96 & 14.05 & $21.37 \pm 2.07$ & $18.21 \pm 1.87$ \\
\hline Lignin (\% DM) & 2.82 & 3.04 & 3.25 & 3.47 & $4.64 \pm 0.24$ & $4.27 \pm 0.53$ \\
\hline
\end{tabular}

\begin{tabular}{lcc}
\hline Period & DM & DMpd \\
\cline { 2 - 3 } & & t/ha \\
\hline First & 4.26 & 2.79 \\
Second & 4.45 & 2.90 \\
Third & 4.28 & 2.88 \\
Average & 4.33 & 2.86 \\
\hline
\end{tabular}

Table 3 - Chemical composition of supplements and of Brachiaria decumbens Stapf

NDICP (\%CP) - protein insoluble in neutral detergent as crude protein percentage; NDFom(n) - neutral detergent fiber correct for ash and protein. ${ }^{*}$ Mean standard error.

${ }^{1}$ Sample of the simulated pasture during the experimental period.

${ }^{2}$ Sample of the simulated grazing obtained during the the period for evaluation of nutritional parameters.

${ }^{3}$ Calculated by the equation: $\mathrm{NFC}=100-(\% \mathrm{CP}+\% \mathrm{NDFom}(\mathrm{n})+\% \mathrm{EE}+\% \mathrm{ash})$. 
with nitrogen compounds to optimize the use of forage and consequently the animal performance, which can be evidenced by the superior performance of animals supplemented regarded to the non-supplemented animals (Table 4).

Although the forage consumed by the animals showed crude protein level higher than the necessary minimal of

$7-8 \%$ of crude protein in the basal diet reported by Lazzarini et al. (2009) as needed for suitable use of neutral detergent fiber of low quality basal forage, it was verified that $42.77 \%$ of this protein was slowly available for the animal, that is, in the form of insoluble neutral detergent insoluble crude protein (NDICP; Table 3), which justifies the use of protein supplement to potentiates degradation of neutral detergent fiber and also to increase the rate of indigestible residual transition with a consequent increase in the pasture dry matter intake.
It can be observed an increase in neutral detergent fiber and indigestible neutral detergent fiber levels in the supplement with the replacement of soybean meal by castor seed meal in the supplement (Table 3). Because of the great amount of hull in castor seed meal, the level of neutral detergent fiber and indigestible detergent fiber is high, approximately 44 and $28 \%$ of the dry matter, respectively. Therefore, as the level of castor seed meal increased in the supplement, the levels of neutral detergent fiber and indigestible neutral detergent fiber increased as well.

Supplemented animals showed greater gains $(\mathrm{P}<0.10$; Table 4) when compared to those which received only mineral mixture. It was not verified effect of inclusion level of castor seed meal on the weight gain $(\mathrm{P}>0.1)$.

It was verified greater intake $(\mathrm{P}<0.10)$ of organic matter, crude protein and non fiber carbohydrate and digested dry matter (kg/day) among supplemented animals compared to

Table 4 - Descriptive levels of probability of contrast among supplemented and no supplemented, regression parameters, initial body weight means, final body weight and daily average gain in for different supplements

\begin{tabular}{|c|c|c|c|c|c|c|c|c|c|c|}
\hline & \multirow{2}{*}{$\begin{array}{l}\text { Mineral } \\
\text { mixture }\end{array}$} & \multicolumn{4}{|c|}{ Castor seed meal (\%) } & \multirow[t]{2}{*}{ CV (\%) } & \multicolumn{4}{|c|}{ Value $-\mathrm{P}^{2}$} \\
\hline & & 0 & 33 & 67 & 100 & & Control & Linear & Quadratic & Cubic \\
\hline Initial body weight (kg) & 210.2 & 213.2 & 209.8 & 208.1 & 211.1 & & & & & \\
\hline Final body weight $(\mathrm{kg})$ & 241.2 & 247.4 & 250.7 & 257.2 & 252.0 & 3.8 & 0.0134 & 0.2205 & 0.2465 & 0.3609 \\
\hline Daily average weight gain & 366.1 & 439.7 & 478.9 & 556.3 & 493.9 & 24.2 & 0.0134 & 0.2205 & 0.2465 & 0.3610 \\
\hline
\end{tabular}

Table 5 - Adjusted means, coefficients of variation and significance of effects for voluntary intake according to castor seed meal levels in the treatments

\begin{tabular}{|c|c|c|c|c|c|c|c|c|c|c|}
\hline Item & $\begin{array}{l}\text { Mineral } \\
\text { mixture }\end{array}$ & \multicolumn{4}{|c|}{ Castor seed meal level (\%) } & CV (\%) & \multicolumn{4}{|c|}{ Value - $\mathrm{P}^{2}$} \\
\hline & & & & & & $\mathrm{kg} / \mathrm{day}$ & & & & \\
\hline Pasture dry matter & 5.322 & 5.641 & 5.717 & 5.495 & 4.768 & 19.9 & 0.8561 & 0.1295 & 0.3321 & 0.9099 \\
\hline Organic matter ${ }^{2}$ & 4.867 & 5.864 & 5.899 & 5.795 & 4.796 & 18.1 & 0.0943 & 0.0569 & 0.1764 & 0.6534 \\
\hline Organic matter pasture & 4.867 & 5.163 & 5.180 & 5.074 & 4.409 & 20.0 & 0.8321 & 0.1667 & 0.3677 & 0.7953 \\
\hline NDFom(n) & 3.621 & 3.835 & 3.791 & 3.789 & 3.305 & 19.6 & 0.8458 & 0.2005 & 0.4248 & 0.6694 \\
\hline PNDF & 3.621 & 3.745 & 3.697 & 3.663 & 3.249 & 20.0 & 0.9174 & 0.2204 & 0.5070 & 0.7485 \\
\hline Non-fibrous carbohydrates 4 & 0.753 & 1.184 & 1.215 & 1.283 & 0.911 & 14.2 & 0.0019 & 0.6508 & 0.0364 & 0.0651 \\
\hline Digested dry matter ${ }^{5}$ & 3.061 & 4.025 & 4.005 & 3.727 & 3.111 & 18.4 & 0.0259 & 0.0113 & 0.2434 & 0.9445 \\
\hline Digested neutral detergent fiber 6 & 2.582 & 2.784 & 2.665 & 2.591 & 2.324 & 19.4 & 0.9681 & 0.0974 & 0.6987 & 0.7821 \\
\hline Total digestible nutrients ${ }^{7}$ & 3.387 & 4.035 & 4.057 & 3.905 & 3.320 & 17.9 & 0.1299 & 0.0521 & 0.2417 & 0.8196 \\
\hline $\mathrm{OM}^{9}$ & 20.8 & 24.2 & 24.5 & 24.4 & 20.4 & 17.4 & 0.1353 & 0.0996 & 0.1755 & 0.6002 \\
\hline OMP & 20.8 & 21.3 & 21.5 & 21.3 & 18.8 & 19.2 & 0.9641 & 0.2632 & 0.3810 & 0.7671 \\
\hline NDFom(n) & 15.4 & 15.8 & 15.7 & 15.9 & 14.1 & 18.8 & 0.9500 & 0.3167 & 0.4412 & 0.6350 \\
\hline iNDF & 4.2 & 4.3 & 4.4 & 4.5 & 4.1 & 18.5 & 0.8277 & 0.6834 & 0.2971 & 0.6955 \\
\hline
\end{tabular}


not supplemented animals, due to higher presence of them in the supplements (Table 5). Measurement of consumed mass effectively digested allows to integrate the effects of supplementation on intake and digestibility; in this study, although it was not observed effect of supplementation on the dry matter intake, it was noted higher intake of digestible dry matter for supplemented animals due to an increase in the digestibility coefficient of the dry matter with supplementation. Among levels of replacement, a negative linear effect of castor seed meal on the intake of dry matter, organic matter, digested neutral detergent fiber, total digestible nutrients and digestible dry matter was observed.

Levels of crude protein in the diet, calculated from the ratio among crude protein total intake (pasture and supplement) and the total intake of dry matter were 7.4, 11.0, 11.2, 9.6 and $8.2 \%$ respectively for the following treatments: mineral mixture, $100 \%$ of soybean meal and 33,67 and $100 \%$ castor meal. The low level of crude protein in the diet for the $\mathrm{CM}_{100}$ treatment was due to the reduction in the consumption of supplement verified in this replacement level.

Although they had regularly consumed the supplement over the experimental period, animals that received only the castor seed meal $\left(\mathrm{CM}_{100}\right.$ - Table 1$)$ as protein source reduced the intake of supplement during the period of evaluation of nutritional parameters. Scraps of the supplement represented approximately $25 \%$ of the total supplements given to the animals.

A quadratic effect was observed $(\mathrm{P}<0.10)$ for the castor seed meal level in the diet on the intake of crude protein and non-fibrous carbohydrate in $\mathrm{kg} /$ day, with critical points maximal answers located over the levels of $16.6 \%$ and 45.23 $\%$ of the castor seed meal, respectively.

According to Oliveira et al. (2010), despite of the higher indigestible fraction of neutral detergent fiber of castor seed meal, around $66 \%$ of the neutral detergent fiber, the quick degradation of the potentially degradable fraction of neutral detergent fiber (NDFpd) and the small size of indigestible neutral detergent fiber particle facilitated the processes of the rumen disappearance of castor seed meal and neutral detergent fiber, facts that can explain the lack of effect ( $P>0.10$; Table 5) on the intake of NDFom(n), regarded the levels of replacement of soybean meal by castor seed meal. When the NDFom(n) intake was expressed in $\mathrm{g} / \mathrm{kg}$ of crude protein, that one did not differ from the levels of replacing soybean meal by castor seed meal, either. The intake of pasture neutral detergent fiber was not affected $(\mathrm{P}>0.10)$ by supplementation; this was not affected by the levels of castor seed meal treated in the supplement, either.
Supplementation increased $(\mathrm{P}>0.10)$ the total apparent digestibility of dry matter, organic matter, crude protein, and non-fibrous carbohydrate. The highest digestibility of dry matter in supplemented animals can be partly due to higher intake of nutritional compounds easy to be digested rather than increase of pasture digestibility inasmuch as total digestibility of NDFom(n) $(\mathrm{P}>0.10)$ did not change in response to supplement intake.

It was noted a negative linear effect of the inclusion level of treated castor seed meal on digestibility of dry matter, organic matter, crude protein and ether extract. Castor seed meal has effective rumen degradation of intermediate crude protein among soybean meal and cotton seed meal (Moreira et al., 2003), which explains the reduction in digestibility of crude protein as the levels of castor seed meal in the supplement increased. It is described in literature observed reductions in rates of ruminal degradation of protein foods treated with alkaline agents (Stern et al., 1994). The mechanism through which alkaline treatment reduces ruminal degradation is related to changes in the structure of proteins caused by denaturing process (NRC, 2001). Therefore, as demonstrated in an in situ trial (Diniz, 2009), the reduction in ruminal degradability of dry matter when treating castor meal with calcium oxide, helps to explain the reduction in total apparent digestibility of dry matter as castor seed meal was increased in the supplements.

The increase of castor seed meals at the expenses of reduction on levels of soybean meal in diets for heifers reduce the metabolically energy intake, a fact evidenced by the decreasing linear effect $(\mathrm{P}<0.10)$ in the intake of digestible dry matter (Table 5), and on the coefficients of total apparent digestibility of dry matter and organic matter (Table 5).

It is possible to infer on the reason of increase in the level of castor seed meal create lower means in the digestibility coefficients (Table 6), when it is noted that the increase in castor seed meal level in the supplement increased the lignin and iNDF levels (Table 3). According to Oliveira et al. (2010), non treated castor seed meal shows high indigestible fraction of NDF (around 66\% of NDF) due to the high levels of cutin, and that the treatment of castor seed meal with calcium oxide do not have effect on the undegradable fraction of NDF. These traits are directly related to the alterations of microbial attack in the food particles, reducing its digestions potential.

There was a quadratic effect of the level of castor seed meal treated with calcium oxide on total apparent digestibility of NDFom(n) $(\mathrm{P}<0.10)$. This fact is important because it evidences that there is a level of castor seed meal (61.68\%) 
replacing soybean meal which minimizes NDFom(n) digestibility. Considering that NDF responds in average for 60 to $80 \%$ of total dry matter of tropical forages, being the energetic source of lowest cost for the bovine production systems in the tropics (Detmann et al., 2004), this negative effect has to be avoided so not to harm the animal performance.

When the performance results (Table 4) are compared to the results of intake (Table 5) and total apparent digestibility (Table 6), it is observed that supplementation promoted an increase in the intake of organic matter, crude protein, ether extract, non fiber carbohydrate, digestible dry matter and TDN and that it also promoted increase in the coefficient of apparent digestibility of dry matter, organic matter, crude protein, ether extract and non-fiber carbohydrate which increased the weight gain in supplemented animals regarded to the non-supplemented ones. However, it is noted a mismatch, where the increase in castor seed meal treated with calcium oxide caused a decreasing linear effect in the intake of dry matter, organic matter, DDM, DNDF and TDN; it was also observed decreasing linear effect of treated castor seed meal level on coefficient of total apparent digestibility of dry matter, organic matter, and crude protein; however it was not noted effect of level of treated castor seed meal on daily weight gain of the animals which received different levels of castor seed meal level treated with calcium oxide. It is believed that the divergences above cited were because of the fact that during the period of evaluation of nutritional parameters, animals from $\mathrm{CM}_{100}$ treatment did not consume all the supplements ( $25 \%$ of remnants was observed), nevertheless, before and after this period, animals consumed the supplement normally.

Requirement of crude protein and TDN by Zebu heifers with body weight equal to $250 \mathrm{~kg}$ and daily gain weight equal to $500 \mathrm{~g}$ are $602.44 \mathrm{~g} /$ day and $3.19 \mathrm{~kg} /$ day, respectively (Valadares Filho, 2006).
In all the treatments, the intake of TDN was higher than the requirements of Zebu heifers of this category to permit daily weight gain close to $500 \mathrm{~g}$. Regarded to intake of crude protein, only the $\mathrm{CM}_{0}, \mathrm{CM}_{33}$ and $\mathrm{CM}_{67}$ treatment allowed crude protein intake equal or higher than to the needed one to permit the same daily weight gain previously cited. The low intake of crude protein observed for animals in the control treatment was due to the low level of this nutrient in the forage, which reduced the weight gain of the animals. For the $\mathrm{CM}_{100}$ treatment, the low intake of crude protein was caused by the reduction in the intake of supplement by the animals during the period of evaluation of nutritional parameters. It is believed that the intake of crude protein before and after this period was equal to or higher than the requirement of crude protein for daily weight gain close to $500 \mathrm{~g}$ because out of the period of nutritional evaluation, the animals consumed normally the supplement and there was no effect of the level of castor seed meal in the supplement on daily weight gain of the animals.

The effect of supplementation more prominent observed in this study can be attributed to increase of nitrogen balance, which was increased from 25.1 to around $45.6 \%$ of total digested $\mathrm{N}$ (Table 7). This effect would result in a direct increase in the weight gain of animals in production (Costa, 2009).

It was verified a quadratic effect $(\mathrm{P}<0.1)$ of the level of castor meal in the diet on NI and nitrogen fecal excretion (NFE), with critical points (maximal answers) located on the levels of $17.03 \%$ and $33.62 \%$ of castor seed meal, respectively. Therefore, the nitrogen balance also showed quadratic effect, with critical point located at the level of $22.03 \%$.

It was not observed supplementation effect as it was not observed effect of castor meal level either $(\mathrm{P}>0.10)$ in the supplement on the flow of microbial nitrogen compounds (NMIC) and on the efficiency of crude protein synthesis

Table 6 - Digestibility coefficients and total digestible nutrients in heifers according to the castor seed meal levels in the supplements

\begin{tabular}{|c|c|c|c|c|c|c|c|c|c|c|}
\hline \multirow[t]{2}{*}{ Item } & \multirow{2}{*}{$\begin{array}{l}\text { Mineral } \\
\text { mixture }\end{array}$} & \multicolumn{4}{|c|}{ Castor seed meal level (\%) } & \multirow[t]{2}{*}{ CV (\%) } & \multicolumn{4}{|c|}{ Value $-\mathrm{P}^{2}$} \\
\hline & & 0 & 33 & 67 & 100 & & Control & Linear & Quadratic & Cubic \\
\hline Dry matter ${ }^{1}$ & 57.51 & 63.25 & 61.99 & 59.69 & 60.28 & 4.1 & 0.0010 & 0.0115 & 0.3292 & 0.3529 \\
\hline Crude protein ${ }^{3}$ & 32.45 & 55.47 & 54.21 & 48.10 & 45.89 & 10.4 & $<0.0001$ & 0.0002 & 0.8008 & 0.3025 \\
\hline Ether extract ${ }^{4}$ & 79.21 & 61.57 & 65.01 & 63.53 & 67.75 & 9.1 & $<0.0001$ & 0.0001 & 0.1037 & $<0.0001$ \\
\hline $\operatorname{NDFom}(n)^{5}$ & 66.34 & 68.47 & 67.39 & 64.08 & 66.51 & 3.3 & 0.6467 & 0.0001 & 0.3998 & 0.1049 \\
\hline
\end{tabular}

NDFom(n) = neutral detergent fiber correct for ash and nitrogenous compounds.

${ }^{1} \hat{Y}=62.9928-0.0337 x\left(r^{2}=0.7946\right) ;{ }^{2} \hat{Y}=67.7472-0.0326 x\left(r^{2}=0.8399\right) ;{ }^{3} \hat{Y}=56.1471-0.1045 x(0.9374) ;{ }^{4} \hat{Y}=61.57+0.2839 x-0,0070 x^{2}+0.000047 x^{3}\left(R^{2}=>0.9999\right) ;$ $\left.5 \hat{Y}=20.7862-0.1246 \mathrm{x}+0.00101 \mathrm{x}^{2}\left(\mathrm{R}^{2}=0.9306\right) ;{ }^{6} \hat{\mathrm{Y}}=75.53+0.02942 \mathrm{x}\left(\mathrm{r}^{2}=0.8678\right) ;{ }^{7} \hat{\mathrm{Y}}=65.70-0.08215 \mathrm{x}+0.000876 \mathrm{x}^{2} \mathrm{R}^{2}=0.8707\right)$. 
Table 7 - Nitrogenous compounds metabolism in heifers according to the cottonseed levels in the supplements

\begin{tabular}{|c|c|c|c|c|c|c|c|c|c|c|}
\hline \multirow[t]{2}{*}{ Item } & \multirow{2}{*}{$\begin{array}{l}\text { Mineral } \\
\text { mixture }\end{array}$} & \multicolumn{4}{|c|}{ Castor seed meal level (\%) } & \multirow[t]{2}{*}{ CV (\%) } & \multicolumn{4}{|c|}{ Value - $\mathrm{P}^{2}$} \\
\hline & & 0 & 33 & 67 & 100 & & Control & Linear & Quadratic & c Cubic \\
\hline Nitrogen intake (g/day) ${ }^{1}$ & 62.7 & 111.9 & 115.4 & 96.5 & 72.3 & 15.8 & $<0.0001$ & $<0.0001$ & 0.0171 & 0.4914 \\
\hline Ureic nitrogen urinary excretion (g/day) & 4.46 & 5.13 & 5.37 & 5.20 & 4.79 & 27.8 & 0.2720 & 0.6161 & 0.5367 & 0.9462 \\
\hline Apparent nitrogen balance ${ }^{3}$ & 15.87 & 56.71 & 57.07 & 40.91 & 28.15 & 18.9 & $<0.0001$ & $<0.0001$ & 0.0285 & 0.1286 \\
\hline $\begin{array}{l}\text { Apparent nitrogen balance expressed in g/day } \\
\text { regarded to intake } \mathrm{N}^{4}\end{array}$ & 0.251 & 0.506 & 0.495 & 0.425 & 0.393 & 12.3 & $<0.0001$ & $<0.0001$ & 0.6025 & 0.2742 \\
\hline Flow of microbial nitrogen compounds (g/day) & 68.04 & 59.52 & 60.88 & 63.81 & 67.68 & 17.8 & 0.3028 & 0.1664 & 0.7736 & 0.9747 \\
\hline $\begin{array}{l}\text { Flow of microbial nitrogen compound regarded to } \\
\text { nitrogen intake ( } g / g \text { of consumed nitrogen })^{6}\end{array}$ & 1.10 & 5.31 & 5.27 & 6.60 & 9.35 & 22.6 & $<0.0001$ & $<0.0001$ & 0.0345 & 0.9637 \\
\hline Purine derivative excretion (mmol/day) & 113.4 & 102.1 & 104.2 & 108.6 & 113.6 & 14.1 & 0.3359 & 0.1439 & 0.8008 & 0.9521 \\
\hline $\begin{array}{l}\text { Microbial synthesis efficiency } \\
\text { (g microbial CP/kg TDN) }\end{array}$ & 122.1 & 106.5 & 106.6 & 110.9 & 121.5 & 22.3 & 0.3238 & 0.2591 & 0.5890 & 0.9650 \\
\hline
\end{tabular}

expressed as g CPmic/kg of digested TDN. The mean value observed for EFM was $113.5 \mathrm{~g}$ of CPmic/kg of digested TDN.

Levels of ureic nitrogen in the serum (UNS) are affected by the nutritional level, especially in ruminants. In general, UNS is a sensitive and immediate indicator of protein intake (Gonzales et al., 2002).

Ureic nitrogen concentration in the serum (UNS) was higher in supplemented animals than in non supplement animals. A quadratic effect was observed under UNS concentration as the level of castor meal increased in the supplement. This variable showed the same behavior in nitrogen intake (Table 7). Levels of castor meal in diet which maximize NI and UNS are $17.03 \%$ and $37.67 \%$, respectively.

Valadares et al. (1997) suggested that levels of plasmatic urea-N between 13.52 and $15.15 \mathrm{mg} / \mathrm{dL}$ corresponds to maximal microbial efficiency and probably it would be the limit from which there is a loss of protein for Zebu heifers fed $62.5 \%$ of TDN. The average level of UNS for supplemented animals was $11.51 \mathrm{mg} / \mathrm{dL}$, which is quite below the minimum value that corresponds to maximum microbial efficiency suggested by Valadares et al. (1997). However, the values of UNS for non supplemented animals was $5.7 \mathrm{mg} / \mathrm{dL}$, a value much lower than the one showed for supplemented animals indicating a possible restrain of microbial activity which could have harmed the performance of non supplemented animals. However, NIMIC and EFM as well were affected by supplementation.

The low value of NMIC/NI for non supplemented animals along with the low coefficient of crude protein total apparent digestibility observed for these animals suggest that their rumen was in negative balance of nitrogen compounds and the recycling might be providing significant quantities of nitrogen to ruminal environment. According to Costa (2009), crude protein ruminal digestibility is negative in diets with ruminal ammoniacal nitrogen levels lower than $10.91 \mathrm{mg} / \mathrm{dL}$. Stimuli on this parameter are obtained up to the level of $12.56 \mathrm{mg}$ NAR/dL. Conversion of these values in terms of dietary crude protein indicates that 10.52 and 11.62 (\% MS) of crude protein are needed to annul and to maximize ruminal apparent digestibility coefficient of crude protein, respectively. Therefore, it is believed in this study that the rumen of the non supplement animals was in negative balance of nitrogen compounds what could have harmed microbial growth and consequently the use of pasture fiber compounds, reflecting in lower daily weight gain for non supplemented animals (Table 4).

\section{Conclusions}

It is suggested the use of protein supplements for grazing beef heifers during the dry/rainy transition season. Castor meal treated with calcium oxide replacing soybean meal in multiple supplements does not harm animal performance, but it affects utilization of the nutrients.

\section{References}

ANUAlpeC. 2007. Anuário da Pecuária Brasileira. Instituto FNP. São Paulo. 2007. 368p.

CASALI, A.O.; DETMANN, E.; VALADARES FILHO, S.C. et al. Influência do tempo de incubação e do tamanho de partículas sobre os teores de compostos indigestíveis em alimentos e fezes bovinas obtidos por procedimentos in situ. Revista Brasileira de Zootecnia, v.37, n.2, p.335-342, 2008.

CHEN, X.B.; GOMES, M.J. Estimation of microbial protein supply to sheep and cattle basid on urinary excretion of purine derivatives-an overview of the technical details. Ocasional publication. Buchsburnd, Aberdeen: Rowett Research Institute, 1992. 21p. 
CHIZZOTTI, M.L.; VALADARES FILHO, S.C.; VALADARES, R.F. et al. Consumo, digestibilidade, excreção de uréia e derivados de purina em novilhas de diferentes pesos. Revista Brasileira de Zootecnia, v.35, p.1813-1821, 2006.

COSTA, V.A. Desempenho nutricional de bovinos em pastejo durante o período das águas com suplementação protéica ou protéico-energetica. 2009. 103f. Tese (Doutorado em Zootecnia) - Universidade Federal de Viçosa, Viçosa, MG.

DETMANN, E.; PAULINO, M.F.; ZERVOUDAKIS, J.T. et al. Cromo e indicadores internos na estimação do consumo de novilhos mestiços, suplementados, a pasto. Revista Brasileira de Zootecnia, v.30, n.5, p.1600-1609, 2001.

DETMANN, E.; ZERVOUDAKIS, J.T.; CABRAL, L.S. et al. Validação de equações preditivas da fração indigestível em detergente neutro em gramíneas tropicais. Revista Brasileira de Zootecnia, v.33, p.1866-1875, 2004.

DETMANN, E.; VALADARES FILHO, S.C.; PINA, D.S. et al. Estimação da digestibilidade do extrato etéreo em ruminantes a partir dos teores dietéticos: desenvolvimento de um modelo para condições brasileiras. Revista Brasileira de Zootecnia, v.35, n.4, p.1469-1478, 2006.

DINIZ, L.L. Desempenho e avaliação nutricional de dietas contendo farelo de mamona para bovinos. 2009. $97 \mathrm{f}$. Dissertação (Mestrado em Zootecnia) - Universidade Federal de Viçosa, Viçosa, MG.

FUJIHARA, T.; ØRSKOV, E.R.; REEDS, P.J. et al. The effect of protein infusion on urinary excretion of purine derivatives in ruminants nourished by intragastric nutrition. The Journal of Agricultural Science, v.109, n.1, p.7-12, 1987.

GONZALES, F.H.D.; SCHEFFER, J.F.S. Perfil sangüíneo: ferramenta na análise clínica, metabólica e nutricional. Avaliação metabólica-nutricional de vacas leiteiras por meio de fluidos corporais. In: CONGRESSO BRASILEIRO DE MEDICINA VETERINÁRIA, 29., 2002, Gramado. Anais... Gramado: 2002. p.5-17.

HALL, M.B.; AKINYODE, A. Cottonseed hulls: working with with a novel fiber source. In: Annual Florida Ruminant Nutrition Symposium, 11., 2000, Gainesville. Proceedings... Gainesville, 2000. p.179-186.

LAZZARINI, I.; DETMANN, E.; SAMPAIO, C.B. Intake and digestibility in cattle fed low-quality tropical forage and supplemented with nitrogenous compounds. Revista Brasileira de Zootecnia, v.38, n.10, p.2021-2030, 2009

LICITRA, G.; HERNANDEZ, T.M.; VAN SOEST, P.J. Standardization of procedures for nitrogen fractionation of ruminant feeds. Animal Feed Science and Technology, v.57, n.4, p.347-358, 1996.

MERTENS, D.R. Gravimetric determination of amylase-treated neutral detergent fiber in feeds with refluxing in beaker or crucibles: collaborative study. Journal of AOAC International, v.85, p.1217-1240, 2002.

MOREIRA, J.F.C.; RODRÍGUEZ, N.M.; FERNANDES, P.C.C. et al. Concentrados protéicos para bovinos. 1. Digestibilidade in situ da matéria seca e da proteína bruta. Arquivo Brasileiro de Medicina Veterinária e Zootecnia, v.55, n.3, p.315-323, 2003.

NATIONAL RESEARCH COUNCIL - NRC. Nutrient requirements of dairy cattle. 7.ed. Washington, DC: National Academic Press, 2001. 381p.

OLIVEIRA, A.S.; OLIVEIRA, M.R.C.; CAMPOS, J.M.S. et al. Eficácia de diferentes métodos de destoxificação da ricina do farelo de mamona. In: CONGRESSO DA REDE BRASILEIRA DE TECNOLOGiA DE BiOdiesel, 2., 2007, Brasília. Anais... Brasília: MCT/ABIPTI, 2007. p.1-6. (CD-ROM).

OLIVEIRA, A.S.; CAMPOS, J.M.S.; OLIVEIRA, M.R.C. et al., Nutrient digestibility, nitrogen metabolism and hepatic function of sheep fed diets containing solvent or expeller castorseed meal treated with calcium hydroxide. Animal Feed Science and Technology, v.158, p.15-28, 2010.

PAULINO, M.F.; DETMANN, E.; VALADARES FILHO, S.C. Bovinocultura funcional nos tópicos. In: SIMPÓSIO DE PRODUÇÃO DE GADO DE CORTE, 6., SIMPÓSIO INTERNACIONAL DE PRODUÇÃO DE GADO DE CORTE, 2., 2008, Viçosa, MG. Anais... Viçosa, MG: VI SIMCORTE, 2008. p.275-305.

SAMPAIO, C.B.; DETMANN, E.; LAZZARINI, I. Rumen dynamics of neutral detergent fiber in cattle fed low-quality tropical forage and supplemented with nitrogenous compounds. Revista Brasileira de Zootecnia, v.38, n.3, p.560-569, 2009

SEVERINO, L.S. O que sabemos sobre a torta de mamona. Campina Grande: Embrapa Algodão, 2005. 31p. (Documentos, 134).

SILVA, D.J.; QUEIROZ, A.C. Análise de alimentos: métodos químicos e biológicos. 3.ed. Viçosa: UFV, 2002. 235p.

STERN, M.D.; VARGA, G.A.; CLARK, J.H. et al. Evaluation of chemical and physical properties of feeds that affect protein metabolism in the rumen. Journal of Dairy Science, v.77, p.2762-2786, 1994.

TITGEMEYER; E.C.; ARMENDARIZ, C.K.; BINDEL, D.J. et al. Evaluation of titanium dioxide as a digestibility marker for cattle. Journal of Animal Science. v.79, p.1059-1063, 2001.

VALADARES FILHO, S.C.; PAULINO, P.V.R.; MAGALHÃES, K.A. Exigências nutricionais de zebuínos e tabelas de composição de alimentos BR-CORTE. Viçosa, MG: UFV, DZO, 2006. 142p.

VALADARES, R.F.D.; BRODERICK, G.A.; VALADARES FILHO, S.C. et al. Effect of replacing alfalfa silage with high moisture corn on ruminal protein synthesis estimated from excretion of total purine derivatives. Journal of Dairy Science, v.82, n.11, p.2686-2696, 1999.

VALADARES, R.F.D.; GONÇALVES, L.C.; SAMPAIO, I.B. et al. Níveis de proteína em dietas de bovinos. 2. Consumo, digestibilidade e balanço de compostos nitrogenados. Revista Brasileira de Zootecnia, v.26, n.6, p.1259-1263, 1997.

VERBIC, J.; CHEN, X.B.; MACLEOD, N.A. et al. Excretion of purine derivatives by ruminants. Effect of microbial nucleic acid infusion on purine derivative excretion by steers. Journal of Agricultural Science, v.114, n.3, p.243-248, 1990. 